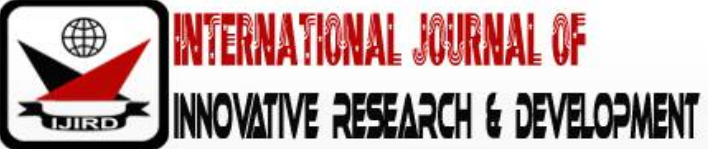

ISSN 2278 - 0211 (Online)

\section{An Assessment of Total Quality Management in Nigerian Private Universities}

\begin{tabular}{c}
\hline Dr. Solomon A. Babarinde \\
Senior Lecturer, Department of Business Administration, \\
Oduduwa University, Nigeria \\
Olusola Olubukunola. O \\
Lecturer, Department of Business Education, \\
Tai Solarin University of Education, Nigeria
\end{tabular}

\begin{abstract}
:
This paper assessed total quality management (TQM) in Nigerian private universities. The specific objectives of the study evaluated total quality management practices implemented in Nigerian private universities; ascertained the quality problems in Nigerian private universities and investigated the degree of conformity of private universities in Nigeria to NUC predetermined quality standards. The study adopted a cross-sectional quantitative research design, which was based on a positivist research philosophy. The population for this study consisted of staff of The Department of Student and Academic Administration of the seventy-nine (79) private universities' in Nigeria. About the sample size, a sample of five hundred staff of The Department of Student and Academic Administration of the private universities (500) were chosen as the sample for the conduct of this study. Structured questionnaires adapted from existing TQM scales was used to collect primary data from the study respondents. Descriptive, reliability, and factor analysis was carried out on the collected data. Study findings revealed the quality management practices in Nigeria private universities to revolve around customer focus and satisfaction, quality leadership, quality information and analysis, Human resource development, strategic planning management, internal quality results, top management commitment, and process management. Study findings through factor analysis also revealed the nature of quality problems experienced by Nigerian private universities to revolve around improvement problem, administrative issues, structural problems, process design problems, unstructured performance problems, efficiency problems, and conformance problems. The study concludes from its investigation of the quality conformance of Nigerian private universities to predetermine standards that conformance to objectives of the university programs is essential in the measurement of TQM in Nigerian private universities, conformance to curriculum, teaching staff and quality ratio, student admission requirements, graduation requirements and conformance to standard of degree examination are important areas that Nigerian private universities have to pay attention to as evidenced from the study findings.
\end{abstract}

Keyword: Assessment, conformance, department, graduate student, Nigerian private university, standard, total quality control, quality

\section{Introduction}

Market forces in the Nigerian business environment are now having a much more significant impact on university education than ever before. Therefore, the operating environment is becoming more intricate and tentative, and the organizational structures in private universities have to acclimatize and transform at an even more significant speed than in the past. Competitiveness, relevance, and conceivably even future survival in the context of Nigerian private universities, will depend to a substantial degree on the ways and methods in which change, quality, and improvement are managed (Gyan, 2018).

Total Quality Management (TQM) is a pattern that can be relied upon by private universities in Nigeria in their bid to manage change, quality, and improvement. TQM has been used and applied successfully and extensively in the manufacturing, commercial, and service context (Muhammad, Malik \& Janjua, 2019). This study assesses TQM in Nigeria private universities.

The growth of private universities in Nigeria has been astounding in terms of the number of private universities that have been set up in the country. This growth in private universities has substantially expanded the availability of education to many Nigerians. Regardless of the increase in the numbers of private universities in Nigeria, the overall capacity of the private universities in Nigeria is still less than the total carrying capacity of public universities in the country.

One challenging fact in the growth of private universities in Nigeria is that not all the private universities in the country can be said to be operating above standard or in line with pre-agreed standards for tertiary education in the 
country. The implication of some of the private universities operating below standard can be seen in the quality of graduate students produced by the universities. Universities operating below standards have a high likelihood of producing graduate students that cannot properly defend the certificate that they have being awarded as evidenced by the graduate students who lack expected skills; can neither speak nor write eloquent English; and are, as a result, unemployable (Diana-Abasi, 2015).

The high rate of unemployment in the country coupled with the poor quality of graduate being churned out by private universities in Nigeria makes it essential for stakeholders in the tertiary education system in the country to begin to anticipate what the future of private universities will be in the country in the future considering the observable fall in standards over the last 10 years (Psomas \& Jiju, 2017). This is where the National Universities Commission comes in because it is the chief regulating officer for the operations of private universities in Nigeria. It becomes important for the assessment of the TQM practices of Nigeria private universities to consider the quality standards the NUC been enforcing in Nigerian private universities.

From all clues, NUC makes use of the regulatory benchmarks developed in the past to evaluate and assess courses and programs for accreditation of private universities in Nigeria. This permits the NUC to accomplish moderately three of its directives, namely, (a) authorization of courses and programs; (b) official approval of academic programs; and (c) determination and maintenance of minimum educational values.

In managing the quality of private universities, the NUC does not only approve or authorize courses, but it also provides guidelines and handling of requests for the creation of private universities and monitoring of universities. These five guidelines establish the NUC's quality codes. When the guidelines and the quality code of the NUC is considered closely and when mandates (a), (b), and (c), are assessed from a quality perspective which has to do with curriculum standardization. It appears that the processes by which courses and programs are accredited by the NUC are cloaked in controversy and mistrust (Ogunnaike, Tairat, Sholarin \& Ezeugwa, 2014).

For comparative purposes, the quality slant of the regulatory body responsible for managing the quality of tertiary education in the United Kingdom which is the UK Quality Assurance Agency for Higher Education is different from the quality slant and approach of Nigeria universities commission. Like the NUC, the UKQAA institutes the quality code and subject-specific standards, which the UK schools use when planning programs of study and guidelines on academic criterions (Rodriguez, Madonna \& Nunilon, 2018).

However, a significant difference between The UKQAA and NUC is that the former goes much beyond the implementation of curriculum guidance and accreditation of courses in universities. It performs other duties to safeguard the maintenance of academic criterions. Initially, it assesses how UK universities maintain their academic standards and circulate the evaluations for public consumption. Furthermore, it scrutinizes anxieties and objections about academic standards and quality, raised by undergraduates, faculty, workforce, and other patrons involved in university education. Thirdly, it delivers training and guidance for the UK universities to develop and expand their quality assurance processes. From the preceding one can see a substantial difference in the way quality is maintained in UK universities when compared to that of Nigeria.

Based on the preceding TQM offers a vehicle for private universities in Nigeria to manage themselves successfully at a season such as this characterized by the sudden change, while maintaining a vibrant focus on the important and overriding purposes of education" (West- Burnham, 1992). There can, conceivably, be no hesitation that the quality of the staff in the Nigerian private universities is essential to the quality of private university education in the country.

\section{Statement of Research Problem}

Concerns have been raised in Nigeria concerning the irritating rate at which the National Universities Commission (NUC) grants license and approval for the establishment of new private universities in different parts of the country. The NUC would have its justification for its high approval rate of various universities in Nigeria however an assessment of total quality management in Nigerian private universities would necessitate the provision of answers to what the NUC has been doing to improve the quality of existing Nigerian private universities.

It appears as if private universities are set up in Nigeria to make money because the principal goal of many of the founders of private universities cannot be said to produce world-class graduates but for the societal purpose of a name for themselves. Nigeria has also witnessed a lot of private universities being established by religious institutions whose aim might not be to produce world-class graduates but to join the committee of religious institutions that can be said to have universities. The preceding claims are easily substantiated by the failure of Nigerian private universities to be ranked among top universities' in the world or Africa. This corroborates the previous affirmations that Nigerian private universities are backward and the same can be said that the Nigerian educational system is.

The unemployment rate in the country is another proof the urgent need to assess total quality management in Nigerian private universities. Every year, private universities approve graduate degree and postgraduate degree certificates to students numbering thousands. Nigerian graduates are not able to create jobs because the quality of learning is largely theoretical, lacking the technical capability to keep up with the developed nations. Private universities in Nigeria lack the technical capability needed to train students to unleash intrinsic and creative potentials needed to create jobs and to create employment in the Nigerian business environment. Quality education and learning should be able to pilot Nigeria's economy toward wealth. The increase in the number of private universities in Nigeria does not matter in its national development, but the quality of those universities. It is based on the preceding that this paper assessed total quality management practices in Nigerian private universities; ascertained the quality problems in Nigerian private universities and investigated the degree of conformity to predetermined standards. 


\section{Literature Review}

Total quality management has several definitions. Fundamentally it has to do with organizational enhancement via the documentation and solution of problems by groups of staffs at several levels in the structure (Bettye, 1996). This problem solving is typically supported by the improvement of teams and single-mindedness on business goals. On the other hand, the teams principally identify with issues of specific applicability to their functions to produce a sense of participation in organizational affairs. TQM is a holistic paradigm which distinguishes that all staffs can make an influence upon the quality of goods and services provided (Venkatraman, 2007).

Consequently, the organization's systems and processes are regarded as very much as its products and outputs. Agreeing to TQM philosophy, the single significant definition of quality is considered as the customers' perceptions of quality. Consequently, private universities in Nigeria must have machinery in place which habitually establishes these customer desires and perceptions. Additionally, private universities in Nigeria must be competent to react to this information in a suitable time frame. In TQM, the concept of a customer has similarly been redefined to consist of internal as well as external customers (Crosby, 1979).

Furthermore, every person in the business is not merely a supplier but likewise a client of someone else. For instance, a third-year lecturer is a customer of the first-year colleague's efforts with the same class. Likewise, the secondyear lecturer is a supplier to his/ her third-year colleague. This twofold role in a supplier/ customer series is a modest but influential way of strengthening shared objectives, a sense of pride in the job, and responsibility.

Apart from being customer centered, TQM similarly stimulates the importance of internal employee relations, since employee optimism, commitment, and enthusiasm are in the end, contributing factor of external customer relations (Paula, 1996).

In conclusion, TQM suggests an emphasis on the cost of quality or more appropriately on the cost of not having quality, i.e., the price of nonconformance (Crosby, 1979). It is extensively acknowledged that this cost in service organizations is characteristical of the order of 20 to 40 percent of operating costs (Kaufman, 1992).

\section{TQM in Universities}

Private universities can be described as open systems since they enjoy most of the qualities initially acknowledged by Katz and Kahn (1996) as characterizing such systems. Specifically: the ingress of vitality from the environment, the input or conversion of the introduced energy into specific product form which is typical of the system, the transferring of that product into the surroundings, and the re-energizing of the system from sources in the environment.

Private universities are similarly represented in a market environment which, to use Porter's (1985) framework, has substantial competitiveness amongst prevailing rivals, competition being founded upon such things as rate, innovative product introduction and, currently to a slighter degree, upon customer service. It is this last point which might demonstrate the significant success factor for individual universities. TQM may be a required and ample means of refining customer service. Along with this intra-system rivalry for resources, there is similarly a noticeable growth in the influence of influential supplier and customer alignments, which are requesting higher quality and better service. For instance, the formation of the Academic Audit Unit, administration guidelines and proposals about student choices through a "voucher system," petitioning from industry and commerce for research which is closer to the market, and the University faculty emphasis on research quality.

\section{Nigerian Private Universities as Service Organisations}

While much present-day thinking on quality has developed from manufacturing backgrounds, it is almost certainly more suitable to compare private universities with service sector establishments. In general, the provision of a service is described by Frances, Hill \& Andrew 1991):

- The degree to which the client is involved in the delivery process itself, i.e., the invention and depletion of the service are temporally attached to a bigger gradation than in a manufacturing setting;

- The hypothetically more adjustable nature of the supplied service, likened with a factory-made product since it is more dependent on the disposition and temperament of the individuals involved;

- The temporariness of the quality of the service, i.e., the customer can merely refer to his/ her memory for future review of the experience.

- Research has revealed that the processes of delivery of services are often of as much importance to the customer as the content of the services themselves, e.g., the cuisine in a high-class restaurant is taken for granted by the customer; what matters to him/ her is how the food is served, presentation style, environment, speed of delivery and courtesy of staff, etc. (Sahney, 2016).

Given this view of services, TQM in universities must apply to all involved in the delivery of those services, before, during and after: Total Quality Management is an approach to improving the effectiveness and flexibility of businesses as a whole (Muhammad, Malik \& Janjua, 2019). It is fundamentally a way of unifying and connecting the whole organization; every section, every activity, every single person at every level. For an organization to be truly effective, each part of it must work properly together, recognizing that every person and every activity affects, and in turn is affected by others (Oakland, 1989).

\section{Research Design}

The study adopts a positivist research paradigm. This implies that the research took a quantitative approach. The research problem was framed based on existing challenges in the Nigerian private universities, which results in the need to assess TQM in Nigerian private universities. Data was gathered through the use of a questionnaire which was 
formulated based on existing scales obtained from relevant studies in TQM. The survey strategy was utilized because of its consistent use in quantitative-based studies. Moreover, a cross-sectional study was preferred, given its ability to capture the specified research phenomenon, which is TQM in private universities in Nigeria at a given point in time (Gray, 2013).

\section{Study Population, Sample Size, and Sampling Technique}

The population for this study consisted of staff of The Department of Student and Academic Administration of the seventy-nine (79) private universities' in Nigeria. Given that it is challenging to conduct a survey on all the staff of The Department of Student and Academic Administration of the seventy-nine (79) private universities' in Nigeria, a theoretical sample was considered relevant and necessary in line with the consensus in relevant literature on the subject matter (Attewel \& Rule, 1991; Malhotra, 1996).

About the sample size, a sample of five hundred staff of The Department of Student and Academic Administration (500) were chosen as the sample for the conduct of this study. The sample size is defensible given that several researchers have acknowledged that a sample size of two hundred (200) is adequate in terms of statistical power for data analysis (Hair et al., 2010; Wilson \& Henseler, 2007).

It was similarly quite challenging to apply a probability sampling procedure that would be closer to gaining a sample commendable of a true reflection of the staff of The Department of Student and Academic Administration of private universities in Nigeria. Given all these challenges made more difficult by the time factor, the nonprobability sampling method was suitable in obtaining a sample for the survey. The study adopted the nonprobability sampling technique of convenience sampling in selecting five hundred (500) the staff of The Department of Student and Academic Administration of private universities in Nigeria.

\begin{tabular}{|c|c|c|}
\hline Constructs & Number of Items & Sources \\
\hline Total Quality Management Practices & 8 & Saraph et al., 1989 \\
\hline Quality Problems & 7 & Parast et al., 2006 \\
\hline Degree of Conformity & 7 & Rao et al., 1999 \\
\hline
\end{tabular}

Table 1: Scale Development Items for Questionnaire

\subsection{Reliability and Validity}

Cronbach's (1951) coefficient alpha and Construct Reliability (CR) were adopted to check for validity, content, construct, criterion, and external validity of the research instrument.

\subsection{Data Analysis Techniques}

The study adopted a Confirmatory Factor Analysis (CFA) to check for the variables that best explained the construct of TQM in Nigeria private universities. CFA is adopted because it is a powerful and flexible technique for assessing unidimensionality (Dunn et al., 1994). Factor analysis allows the researcher to know how indicators of the construct fit in a single-factor model (Hair et al., 1998). This approach holds great significance due to its ability to offer precise tests for the convergent and discriminant validity of factor measurement (Anderson \&Gerbing, 1988). Hair et al. (2010) have advocated that in using CFA, a factor loading of .50 and above on a quantified factor is satisfactory. This threshold was embraced in this study.

\subsection{Descriptive Statistics}

The data collected were examined for normality using skewness and kurtosis with the criterion that it must fall within the range of +1 or -1 .

\begin{tabular}{|c|c|c|c|c|}
\hline Items & Mean & SD & Skewness & Kurtosis \\
\hline TQM Practices & & & & \\
\hline TQM1 & 3.88 & 1.02 & -0.57 & 0.07 \\
\hline TQM2 & 3.71 & 0.96 & -0.87 & 0.79 \\
\hline TQM3 & 3.75 & 1.00 & -0.89 & 0.45 \\
\hline TQM4 & 3.77 & 1.12 & -0.68 & 0.06 \\
\hline TQM5 & 3.75 & 0.98 & -0.93 & 0.84 \\
\hline TQM6 & 3.69 & 1.03 & -0.64 & 0.09 \\
\hline TQM7 & 3.41 & 0.60 & -0.87 & 0.61 \\
\hline TQM8 & 3.73 & 0.87 & -0.79 & 0.43 \\
\hline Quality Problems & & & & -0.44 \\
\hline QP1 & 3.47 & 0.86 & -0.21 & -0.17 \\
\hline QP2 & 2.87 & 0.97 & 0.07 & -0.79 \\
\hline QP3 & 3.17 & 1.12 & 0.02 & -0.58 \\
\hline QP4 & 3.13 & 1.01 & -0.04 & 0.86 \\
\hline QP5 & 3.36 & 1.12 & -0.19 & 0.20 \\
\hline QP6 & 3.74 & 0.87 & -0.69 & \\
\hline
\end{tabular}




\begin{tabular}{|c|c|c|c|c|}
\hline Items & Mean & SD & Skewness & Kurtosis \\
\hline QP7 & 3.69 & 0.94 & -0.56 & 0.13 \\
\hline Quality conformity & & & & \\
\hline QC1 & 3.57 & 1.21 & -0.57 & -0.53 \\
\hline QC2 & 3.30 & 1.19 & -0.28 & -0.19 \\
\hline QC3 & 3.91 & 1.21 & -0.70 & -0.41 \\
\hline QC4 & 3.71 & 1.05 & -0.32 & -0.75 \\
\hline QC5 & 3.72 & 1.03 & -0.43 & -0.19 \\
\hline QC6 & 3.73 & 1.07 & -0.59 & -0.19 \\
\hline QC7 & 3.69 & 0.90 & -0.12 & -0.71 \\
\hline
\end{tabular}

Table 2: Test of Normality

\subsection{Factor Analysis Loadings Table}

The factor loadings table represents an indicator of how well TQM indicators measure the assigned construct, which is the assessment of TQM in Nigeria private university. Based on consensus in research, factor loadings with readings of 0.50 and beyond are considered to satisfactorily measure the concepts they have been assigned to (Falk \& Miller, 1992).

\begin{tabular}{|c|c|c|c|c|c|}
\hline Items & Factor Loading & t-value & $\mathbf{R}^{2}$ & CR & $\begin{array}{c}\text { Cronbach's } \\
\text { coefficient alpha } \boldsymbol{\alpha}\end{array}$ \\
\hline TQM Practices & & Fixed & & 0.85 & 0.89 \\
\hline TQM1 & $0.75^{* * *}$ & 10.57 & 0.51 & & \\
\hline TQM2 & $0.79^{* * *}$ & 11.10 & 0.67 & & \\
\hline TQM3 & $0.84^{* * *}$ & 14.31 & 0.79 & & \\
\hline TQM4 & $0.61^{* * *}$ & 9.11 & 0.33 & & \\
\hline TQM5 & $0.74^{* * *}$ & 10.1 & 0.60 & & \\
\hline TQM6 & $0.69^{* * *}$ & 8.05 & 0.49 & & \\
\hline TQM7 & $0.81^{* * *}$ & 13.40 & 0.72 & & \\
\hline TQM8 & $0.66^{* * *}$ & 9.99 & 0.39 & & \\
\hline Quality Problems & & Fixed & & 0.78 & \\
\hline QP1 & $0.85^{* * *}$ & 12.33 & 0.71 & & \\
\hline QP2 & $0.63^{* * *}$ & 7.10 & 0.47 & & \\
\hline QP3 & $0.79^{* * *}$ & 10.34 & 0.69 & & \\
\hline QP4 & $0.53^{* * *}$ & 5.11 & 0.40 & & \\
\hline QP5 & $0.88^{* * *}$ & 13.10 & 0.80 & & \\
\hline QP6 & $0.90^{* * *}$ & 16.34 & 0.89 & & \\
\hline QP7 & $0.74^{* * *}$ & 9.40 & 0.75 & & \\
\hline Quality Conformity & & Fixed & & 0.81 & \\
\hline QC1 & $0.84^{* * *}$ & 17.01 & 0.75 & & \\
\hline QC2 & $0.88^{* * *}$ & 19.21 & 0.81 & & \\
\hline QC3 & $0.70^{* * *}$ & 15.13 & 0.70 & & \\
\hline QC4 & $0.77^{* * *}$ & 16.02 & 0.78 & & \\
\hline QC5 & $0.73^{* * *}$ & 13.01 & 0.69 & & \\
\hline QC6 & $0.62^{* * *}$ & 10.97 & 0.60 & & \\
\hline QC7 & $0.51^{* * *}$ & 9.90 & 0.59 & & \\
\hline
\end{tabular}

Table 3: Factor Analysis Loading Table

\subsection{Interpretation of Results}

Table 2 presents summaries of the results of the factor analysis conducted to test the multidimensionality of the constructs. The study assessed TQM in Nigerian private universities by investigating the total quality management practices implemented in Nigerian private universities. The factor loading structure from the analysis revealed that the items used to measure TQM practices had strong factor loading with TQM3 having the highest factor loading of $0.84, \mathrm{t}$ value of 14.31 and $\mathrm{R}^{2}$ value of 0.79 . On the scale, TQM3 represents customer focus and satisfaction. TQM1 represents quality leadership, TQM2 represents Quality information and analysis, TQM4 represents Human resource development, TQM5 represents strategic planning management, TQM6 represents internal quality results, TQM7 represents top management commitment, while TQM8 represents process management. From the factor loading structure in table 2, all the items used to measure TQM practices had factor loadings within the acceptable range of 0.50 as posited by Hair et al. (2010). The t-values all produced satisfactory results, whereas the results for the $\mathrm{R}^{2}$ also fell within an acceptable range. TQM3 and TQM7 representing customer focus, satisfaction, and top management commitment had the most substantial factor loading, most robust $t$ value and R2 value signifying the significance of customer focus, satisfaction and top management commitment in the assessment of the quality of Nigerian private universities. CR in the table refers to construct reliability. The $\mathrm{CR}$ value of TQM practices provided evidence of unidimensionality and indicated that the 
constructs were suitable. These Cronbach alpha values of TQM practices fell within an acceptable range and indicated a strong internal consistency.

The study assesses TQM in Nigerian private universities' by investigating the nature of the quality problems experienced by the institutions under study. The factor loading structure and $t$ values ascertained the quality problems in Nigerian private universities to center around seven items on the scale with factor loading values confirming QP1 which represent improvement problem, QP2 which represents administrative problems, QP3 which represents structural problems, QP4 which represents process design problems, QP5 which represents unstructured performance problems, QP6 which represents efficiency problems and QP7 which represents conformance problems. QP1, QP3, QP5, QP6, and QP7 showed strong factor loading, t values, and significant R2 values. The implication of the study finding is that improvement problem, structural problems, unstructured performance problems, efficiency problems, and conformance problems appear to be the most significant area of quality challenges experienced by the private universities' in Nigeria.

Finally, in assessing TQM in Nigerian private universities, the study investigated the degree of quality conformity to predetermined standards. The analysis of quality conformity to predetermined criteria exhibited strong factor loadings. The items exhibiting the strong factor loading allows the investigator to understand the nature of the variables that make up quality conformity in Nigerian private universities under study. QC1, which represents conformity to objectives of the university programs, showed a strong factor loading of 0.84 , strong $t$ value of 17.01 , and robust R2 value of 0.75 . QC2 which represents conformity to curriculum also had a strong factor loading of 0.88 , $t$ value of 19.21 and $R 2$ value of 0.81 signifying that conformity to the curriculum is a strong measure of quality conformance in Nigeria private universities under study. QC3 which represents conformance to teaching staff and quality had a strong factor loading of 0.70 , and so did QC4 which represents conformance to student admission requirements which had a strong factor loading of 0.77 , while QC5 which represents conformance to graduation requirements with a factor loading of 0.73. QC6 and QC7, which represents conformance to the standard of degree examination and conformance to required physical facilities having factor loadings of 0.62 and 0.51 .

\section{Conclusion}

The study focused on the assessment of total quality management in Nigerian private universities. The study assessed TQM in Nigerian private universities from three dimensions using factor analysis. TQM was assessed via the TQM practices in Nigeria private universities, TQM was also assessed via the areas of quality problems experienced by Nigerian universities, and lastly, TQM was examined via quality conformance to predetermined quality standards in alignment with conformance areas established by the Nigeria Universities Commission.

The study concludes the total quality management practices implemented in Nigerian private universities center around customer focus and satisfaction, quality leadership, quality information and analysis, Human resource development, strategic planning management, internal quality results, top management commitment, and process management. Customer focus, satisfaction, and top management commitment had the strongest factor loading, strongest t value and R2 value signifying the significance of customer focus, satisfaction and top management commitment in the assessment of the quality of Nigerian private universities. The study is in line with the studies of Salami \& Akpobire (2013) who affirmed the relevance of customer focus, and the university management commitment to TQM. The study finding is also in line with Deming's (1986) TQM principles which affirmed that employees of private universities want to satisfy their customer base which is the students and parents, but top management's (Vice Chancellors/Provost/ Rectors) have the responsibility according to the finding of the study to enable them to do so by repetitively endeavoring to improve the system in which they work.

The study assessed TQM in Nigerian private universities' by investigating the nature of the quality problems experienced by the institutions under study. The study concludes that the nature of quality problems experienced by Nigerian private universities revolve around improvement problem, administrative problems, structural problems, process design problems, unstructured performance problems, efficiency problems, and conformance problems. The study concludes that among the quality problems experienced that improvement problems, structural problems unstructured performance problems, and efficiency problems are some of the key areas where Nigerian private universities' have to improve on in terms of the application of TQM. This is in line with findings such as Adediran \& Oyelude (2016) affirmed the presence of contemporary problems in Nigeria private university that affects quality. Problems that are administrative. According to Adediran \& Oyelude (2016), the areas of quality problems in Nigeria universities can be remedied with strong accountability frameworks. The present study affirms that such would not be effective with the commitment of the school management, especially the top management.

The study concludes from its investigation of the quality conformance of Nigerian private universities to predetermine standards that conformance to objectives of the university programs is very important in the measurement of TQM in Nigerian private universities. Conformance to curriculum, conformance to teaching staff and quality ratio, conformance to student admission requirements and conformance to graduation requirements are important areas that Nigerian private universities have to pay attention to as evidenced from the study findings. Conformance to the standard of degree examination is also considered necessary, as evidenced by previous research. For case in point, Diana-Abasi (2015) carried out a study on solving the problem of poor quality of university graduates in Nigeria and discovered that low degree of conformance to the standard of degree examination results in low-quality graduates. The author then proposed Joint Graduation, Convocation, and Certification Programme (JGCCP) - which would involve universal testing and certification of graduates in Nigeria. 


\section{Recommendations}

Based on the study findings, the following suggestions are proffered:

- That Nigerian private universities should be mindful in the application of TQM to ensure customer satisfaction that some of the traditions of universities are different from those of manufacturing companies. For case in point, the significance given to scholarship, brilliance, originality, novelty, and genius is not appreciated to the same degree elsewhere. Consequently, the terminology of TQM may need to be adapted to make it suitable and tolerable to private universities in Nigeria.

- Additionally, the conception of external customers, while legal in itself, may induce some resentment owing to its commercial connotations. There would similarly look as if there is certain misperception about who the external customers of private universities in Nigeria are, e.g., government, the NUC, research councils, accreditation bodies, students, and employers. The study recommends that the mission and objectives of private universities in Nigeria need clarification since this will help in managing the resolving the quality problems identified in this study.

- The study revealed certain quality problems to revolve around, efficiency, process management, administrative and structural lapses for this to be remedied this paper recommends that private universities should consider the idea of employees as internal customers who also need to be satisfied. To remedy the identified quality conformance issues identified in this study, it is recommended that Nigerian private universities implement radical changes to organizational and administrative structures and perhaps more importantly, to attitudes.

\section{References}

i. Attewell, P., \& Rule, J. B. (1991). Survey and Other Methodologies Applied to IT Impact Research: Experiences from a Comparative Study of Business Computing. In the Information Systems Research Challenge: Survey Research Methods- (Kraemer K L, Ed.), 3:299-315, Harvard Business School Press, Boston, MA.

ii. Bettye, B. (1996). How can institutions of higher education achieve quality within the new economy? Total Quality Management 7, 153-160.

iii. Crosby, P. (1979). Quality is Free, The Art of Making Quality Certain. McGraw-Hill, New York, 1979.

iv. Diana-Abasi, I. (2015). Solving the Problem of Poor Quality of University Graduates in Nigeria-A Proposed Holistic Approach. British Journal of Education 3. 52-70.

v. Dunn, S. C., Seaker, R. F., \& Waller, M. A. (1994). Latent variables in business logistics research: scale development and validation. Journal of Business Logistics, 15, 145-145.

vi. $\quad$ Falk, R.F., \& Miller, N.B. (1992). A Primer for Soft Modeling. The University of Akron Press, Akron: Ohio.

vii. Frances, M., Hill, W. \& Andrew, T. (1991). Total Quality Management in Higher Education. International Journal of Educational Management, 5(5)

viii. Gyan, P. (2018). Quality in higher education institutions: insights from the literature. The TQM Journal, 30(6), 732-748, https:// doi.org/ 10.1108/ TQM-04-2017-0043

ix. Hair, J.F.J., Black, W.C., Babin, B.J., \& Anderson, R.E. (2010). Multivariate data analysis (7 ed.). Pearson Prentice Hall.

x. Juran, J. \& Gryna, F. (1980). Quality Planning and Analysis. McGraw-Hill, New York

xi. Katz, D. \& Kahn, R. (1966). The Social Psychology of Organisations, Wiley and Sons, New York, 1966.

xii. Kaufman, R (1992). The challenge of Total Quality Management in Education. Inter.J. Edu. Reform, 1(2): 14-65

xiii. Malhotra N.K. (1996). Marketing Research an applied orientation (2nd ed.). Prentice-Hall: New Jersey.

xiv. $\quad$ Muhammad, K., Malik, S. \& Janjua, S. (2019). Total Quality Management practices and work-related outcomes: A case study of higher education institutions in Pakistan. International Journal of Quality \& Reliability Management, 36(6), 864-874, https:/ / doi.org/ 10.1108/ IJQRM-04-2018-0097

xv. Ogunnaike, O., Tairat, T., Sholarin, A. \& Ezeugwa, I. (2014). An Empirical Analysis of Total Quality Management and Perceived Corporate Image in Higher Education Management. European Scientific Journal 10(22)

xvi. Paula, K. (1996). Application of total quality management in education: retrospect and prospect. International Journal of Educational Management 10:5, 25-35.

xvii. Porter, M. (1985). Competitive Advantage, Creating and Sustaining Superior Performance. Free Press, CollierMacmillan, London.

xviii. Psomas, E. \& Jju A. (2017). Total quality management elements and results in higher education institutions: The Greek case. Quality Assurance in Education, 25(2), 206-223, https:/ / doi.org/ 10.1108/ QAE-08-2015-0033

xix. Rodriguez, R., Madonna, V. \& Nunilon, A. (2018). TQM paradigm for higher education in the Philippines. Quality Assurance in Education, 26(1), 101-114, https:/ / doi.org/ 10.1108/ QAE-12-2015-0048

xx. Sahney, S. (2016). Use of multiple methodologies for developing a customer-oriented model of total quality management in higher education. International Journal of Educational Management, 30(3), 326-353, https:/ / doi.org/ 10.1108/ IJEM-09-2014-0126

xxi. Salami, C. (2009). Assessing Quality Assurance in Nigerian Universities. Oniong: A Contemporary Studies, 1(1): 141-155.

xxii. Salami, C. \& Akpobire, U. (2013). Application of total quality management to the Nigerian education system. Global Advanced Research Journal of Educational Research and Review 10(22)

xxiii. Saraph, J. V., Benson, P. G. and Schroeder, R. G. (1989) 'An instrument for measuring the critical factors of quality management'. Decision Sciences, 20(4), 810-829

xxiv. Venkatraman, S. (2007). A framework for implementing TQM in higher education programs. Quality Assurance in Education, 15(1), 92-112 http:/ / dx.doi.org/ 10.1108/ 09684880710723052 
xxv. West-Burnham, J. (1992). Total quality management in education, in N. Bennett, M. Crawford \& C. Riches (Eds) Managing Change in Education. London: PCP

xxvi. Wilson, B. \& Henseler, J., (2007). Modelling Reflective Higher-order Constructs Using Three Approaches with PLS Path Modelling: A Monte Carlo Comparison. Australian and New Zealand Marketing Academy Conference, Otago, Australia, 791e800 